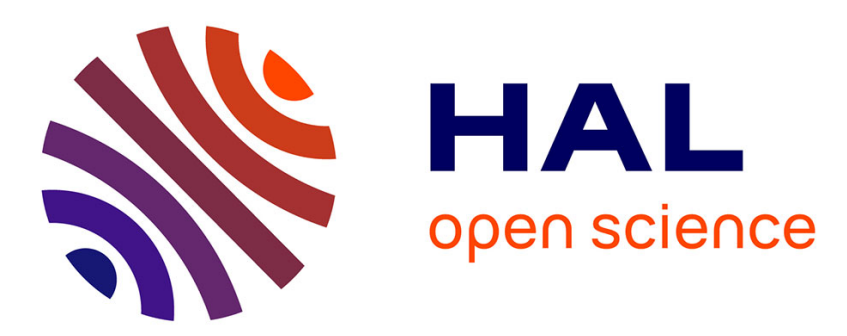

\title{
Quorum sensing in veterinary pathogens: mechanisms, clinical importance and future perspectives
}

\author{
F. Boyen, V. Eeckhaut, F. van Immerseel, F. Pasmans, R. Ducatelle, F. \\ Haesebrouck
}

\section{- To cite this version:}

F. Boyen, V. Eeckhaut, F. van Immerseel, F. Pasmans, R. Ducatelle, et al.. Quorum sensing in veterinary pathogens: mechanisms, clinical importance and future perspectives. Veterinary Microbiology, 2009, 135 (3-4), pp.187. 10.1016/j.vetmic.2008.12.025 . hal-00485527

\section{HAL Id: hal-00485527 \\ https://hal.science/hal-00485527}

Submitted on 21 May 2010

HAL is a multi-disciplinary open access archive for the deposit and dissemination of scientific research documents, whether they are published or not. The documents may come from teaching and research institutions in France or abroad, or from public or private research centers.
L'archive ouverte pluridisciplinaire HAL, est destinée au dépôt et à la diffusion de documents scientifiques de niveau recherche, publiés ou non, émanant des établissements d'enseignement et de recherche français ou étrangers, des laboratoires publics ou privés. 


\section{Accepted Manuscript}

Title: Quorum sensing in veterinary pathogens: mechanisms, clinical importance and future perspectives

Authors: F. Boyen, V. Eeckhaut, F. Van Immerseel, F.

Pasmans, R. Ducatelle, F. Haesebrouck

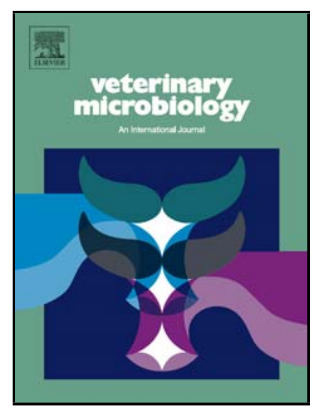

PII:

S0378-1135(08)00606-8

DOI: doi:10.1016/j.vetmic.2008.12.025

Reference: VETMIC 4310

To appear in: $\quad$ VETMIC

Received date: $\quad 1-10-2008$

Revised date: $\quad 23-12-2008$

Accepted date: $\quad 24-12-2008$

Please cite this article as: Boyen, F., Eeckhaut, V., Van Immerseel, F., Pasmans, F., Ducatelle, R., Haesebrouck, F., Quorum sensing in veterinary pathogens: mechanisms, clinical importance and future perspectives, Veterinary Microbiology (2008), doi:10.1016/j.vetmic.2008.12.025

This is a PDF file of an unedited manuscript that has been accepted for publication. As a service to our customers we are providing this early version of the manuscript. The manuscript will undergo copyediting, typesetting, and review of the resulting proof before it is published in its final form. Please note that during the production process errors may be discovered which could affect the content, and all legal disclaimers that apply to the journal pertain. 
QUORUM SENSING IN VETERINARY PATHOGENS: MECHANISMS, CLINICAL

$$
\text { IMPORTANCE AND FUTURE PERSPECTIVES }
$$

\section{F. Boyen, V. Eeckhaut, F. Van Immerseel, F. Pasmans, R. Ducatelle and F. Haesebrouck}

Department of Pathology, Bacteriology and Avian Diseases, Faculty of Veterinary Medicine, Ghent University, Salisburylaan 133, 9820 Merelbeke, Belgium filip.boyen@UGent.be

\section{ABSTRACT}

Under certain circumstances the individuals of a bacterial population may find advantages in acting together and making "collective decisions". This phenomenon is better known as quorum sensing. When the concentration of signal molecules produced by the surrounding bacteria exceeds a certain threshold, the bacterial population acts as a single organism, collectively expressing virulence genes, biofilm forming genes, etc. Several mechanisms of quorum sensing are discussed, each with its distinct signal molecules and respective receptors. Some of these mechanisms are restricted to sensing intraspecies signalling, but interspecies and even interkingdom signalling have also been described. Several veterinary pathogens such as Staphylococcus aureus, Staphylococcus pseudintermedius, Pseudomonas aeruginosa and Salmonella Typhimurium use quorum sensing as a means to optimize virulence gene expression and host colonization. Therefore, targeting of the QS mechanisms may provide a novel strategy for combating bacterial infections, also in veterinary medicine.

\section{Key words: quorum sensing, signal molecules, veterinary pathogens}


INTRODUCTION

The communication mechanism that enables bacteria to make 'collective decisions' is called 'quorum sensing'. For this purpose, small chemical signal molecules are synthesized and secreted into the environment. By using specific detection systems to sense the concentration of these signal molecules, the surrounding bacteria are aware of the bacterial cell density. When the signal molecule concentration reaches a critical threshold, the gene expression and, as a result, the behaviour of the total population is changed (Figure 1).

Quorum sensing (QS) was first described in the 1970s, when Nealson and colleagues (1970) investigated the bioluminescence of Vibrio fischeri and Vibrio harveyi. Ever since, QS has been assigned a role in various mechanisms of gene regulation: biofilm formation (Haesebrouck et al., 2007; Irie and Parsek, 2008), virulence adaptation (Salmond et al., 1995; Vendeville et al., 2005), the production of antimicrobial substances (Salmond et al., 1995; Kleerebezem, 2004), motility (Bearson and Bearson, 2007; Atkinson et al., 2008), sporulation (Lazazzera, 2000), etc. Although these mechanisms have mostly been studied in nonpathogenic bacteria or in human pathogens, the last few years, more studies have been conducted focusing on bacterial species of veterinary importance. of QS by bacterial pathogens of veterinary importance, and possible applications in future veterinary medicine are reviewed. 
MECHANISMS OF QUORUM SENSING

Quorum sensing in Gram positive bacteria: autoinducing polypeptides

Gram positive bacteria mainly use post-translational modified oligopeptides as QS signal molecules (Lyon and Novick, 2004). These autoinducing polypeptides (AIPs) are made up of 5 to 17 amino acids with side chain modifications consisting, for example, of isoprenyl groups (Bacillus spp.) or thiolactone rings (Staphylococcus spp.) (Ji et al., 1997; Lyon and Novick, 2004). The AIPs are synthesized in the cytoplasm as precursor peptides, and then cleaved, modified and transported to the extracellular environment (Lyon and Novick, 2004). In the surroundings of the producing bacterial cell, the AIPs can be detected by membranebound two-component detection systems. Detection of the AIPs by the sensorial part of the two-component systems leads to phosphorylation and therefore activation of the response regulator protein (Lyon and Novick, 2004; Waters and Bassler, 2005). This response protein interacts with the target promoter DNA and the expression of the QS regulated genes is switched on (Figure 2).

The structure of the signal peptide varies between different Gram positive species. Since the binding efficiency on the receptors is highly dependent on the chemical structure of the AIPs, it is generally accepted that mainly Gram positive, but also some Gram negative bacteria use this system for intraspecies communication (Goerke et al., 2003; Dirix et al., 2004; Novick and Geisinger, 2008).

\section{Quorum sensing in Gram negative bacteria: N-acylhomoserine lactones}


In Gram negative bacteria, the signal molecules are $\mathrm{N}$-acylhomoserine lactones

(AHLs), which are also called autoinducer 1 (AI-1). They consist of a conserved homoserine lactone ring which is connected to an acyl side chain of variable length (4 to 18 carbon atoms) and variable extra modification. AHLs with a short acyl side chain can diffuse passively in and out the bacterial cell (Moré et al., 1996; Fuqua et al., 2001). This is in contrast with AHLs with a long acyl side chain and the AIPs, which need active transport mechanisms to cross the bacterial cell membrane (Fuqua et al., 2001; Novick and Geisinger, 2008).

LuxI homologous proteins play a major role in the synthesis of the AHLs, which increase in concentration as the cell density increases. At a critical concentration, LuxR homologues bind the signal molecules and subsequently regulate gene transcription (Fuqua et al., 2001; Waters and Bassler, 2005) (Figure 2). It is becoming more and more obvious, however, that there is a considerable diversity in the way in which the LuxI and LuxR homologues from different bacterial species operate (Smith et al., 2006). Since the LuxR type proteins only detect specific AHLs, this QS system is also mainly used for intraspecies communication. Nevertheless, LuxR type proteins that are able to detect several AHLs have been described. For example, SdiA of Salmonella is believed to be mainly involved in interspecies bacterial communication (Walters and Sperandio, 2006).

\section{Quorum sensing in both Gram positive and Gram negative bacteria: autoinducer 2}

In the late 1990s, a second QS system was discovered in various Gram negative bacteria (Surette et al., 1999). In this system, the autoinducer (AI-2) is a furanosyl borate ester that is formed by the LuxS protein (Waters and Bassler, 2005). To date, AI-2 has been described in more than 50 different bacterial species, comprising both Gram positive and Gram negative bacteria (Surette et al., 1999; Schauder et al., 2001; Hardie and Heurlier, 2008). In Vibrio harveyi, the receptor for the AI-2 molecules is the periplasmatic LuxP 
protein. The LuxP-AI-2 complex binds to a second protein, LuxQ, which is a two-component protein that contains both a sensor kinase domain and a response regulator domain (Neiditch et al., 2005). In low bacterial concentrations, and therefore in the absence of the AI-2, LuxQ phosphorylates LuxO with the aid of the LuxU intermediary protein, which in turn activates the transcription of a repressor protein blocking the transcription of the luciferase operon. At high bacterial densities, the AI-2 presence induces the phosphatase activity of LuxQ, which inactivates LuxO, resulting in the LuxR mediated transcription of the luciferase operon (Neiditch et al., 2005) (Figure 2). The LuxR component of this system should not be confused with the LuxR protein of Vibrio fischeri (see above). The autoinducer AI-2 could serve as a 'universal signal' for interspecies communication (Xavier and Bassler, 2003), though in most enteric bacteria the genes that are directly regulated by $\mathrm{AI}-2$ code for an $\mathrm{ABC}$ transporter system and it has been suggested that the role of AI-2 is mainly metabolic (Vendeville et al., 2005; Walters and Sperandio, 2006; Rezzonico and Duffy, 2008).

\section{Quorum sensing beyond bacterial borders: autoinducer 3}

Enterohaemorrhagic Eschericia coli (EHEC) is the cause of various food-borne outbreaks of severe intestinal disease and the causative agent of the hemolytic uremic syndrome (HUS) and thrombotic thrombocytopenic purpura (TTP) in humans (Moxley et al., 2004; Karch et al., 2005). EHEC motility and attaching and effacing virulence genes are regulated by a QS mechanism (Moxley et al., 2004) that involves the poorly characterized auto inducer 3 (AI-3), which is produced by several enteric bacterial species (Kendall and Sperandio, 2007). Since epinephrine/norepinephrine induce the same virulence gene expression in EHEC and since the effects of AI-3 can be inhibited by adrenergic receptor antagonists, AI-3 probably is structurally similar to epinephrine/norepinephrine (Sperandio et al., 2003). In addition, the presence of epinephrine/norepinephrine itself may serve as a QS 
signal. Apart from the EHEC QseE/F two-component system, QseB/C has been identified as

124 the receptor/response regulator of both AI-3 and epinephrine/norepinephrine in a number of

125 bacterial species (Clarke et al., 2006; Walters and Sperandio, 2006) (Figure 2). Therefore, this

126 adrenergic receptor is thought to play a role in interkingdom signaling (Kendall and 127 Sperandio, 2007).

\section{CLINICAL SIGNIFICANCE OF QUORUM SENSING IN VETERINARY PATHOGENS}

\section{Staphylococcus aureus}

The agr (accessory gene regulator) QS system in Staphylococcus aureus (S. aureus) is one of the most studied QS mechanisms in Gram positive bacteria. Using sequence analysis, S. aureus can be divided into 4 different agr specific groups. The AIPs of one agr group inhibit the expression of the agr expression of the other groups (Novick, 2003). Several haemolysins, enterotoxins, exfoliating toxins, enzymes and surface proteins are regulated by $a g r$. Therefore $a g r$ has been assigned various functions in the pathogenesis of $S$. aureus 138 infections in several animal species.

In rabbits, $S$. aureus infections lead to skin infections, mastitis and internal abscessation. Low virulent strains may occasionally infect an individual animal, while highly virulent strains are the cause of chronic problems and they spread rapidly throughout the rabbitry (Vancraeynest et al., 2006). It has been shown that highly virulent strains are clonal

143 and grouped into agr type IV (Vancraeynest et al., 2006). In addition, it has been shown that

144 agr deletion mutants are attenuated in their capacity to induce endocarditis, osteomyelitis and

145 endophtalmitis in rabbits (Cheung et al., 1994; Gillaspy et al., 1995; Booth et al., 1995).

147 intramammary infections. In contrast to highly virulent rabbit associated $S$. aureus isolates, 
148 strains from bovine mastitis cases are predominantly classified in $a g r$ group I and to a lesser

149 extent in agr groups II and III (Buzzola et al., 2007; Vautor et al., 2008). Bovine S. aureus

150 strains belonging to agr group I show significantly increased capacities to be internalized in

151 bovine mammary epithelial cells and persist in higher numbers in murine mammary glands

152 (Buzzola et al., 2007), while $a g r$ group II strains might prefer the extracellular niche and

153 therefore might be more dependent on biofilm formation (Melchior et al., 2009). In addition,

154 it has been suggested that penicillin resistance in bovine $S$. aureus strains is correlated to the 155 presence of agr group I genes (Melchior et al., 2009).

156 In contrast, for example, to Pseudomonas aeruginosa, biofilm formation in $S$. aureus is

157 negatively regulated by the main QS system. Agr dependent expression contributes to the 158 detachment of biofilms and subsequent colonization of new sites (Boles and Horswill, 2008).

159 Therefore, although still speculative, the QS dependent detachment from biofilms may render 160 some $S$. aureus strains more capable of spreading through a herd and causing chronic 161 problems at the herd level (e.g. highly virulent rabbit strains). This may also explain why $162 a g r+$ and $a g r-$ variants of $S$. aureus might have a cooperative interaction in certain types of 163 infections (Traber et al., 2008).

Staphylococcus pseudintermedius

167 intermedius) are currently assembled in the so-called S. intermedius group (SIG), consisting

168 of $S$. intermedius, Staphylococcus pseudintermedius (S. pseudintermedius) and

169 Staphylococcus delphini (S. delphini) (Hajek, 1976; Varaldo et al., 1988; Devriese et al., 170 2005; Devriese et al., 2009). From a clinical point of view, S. pseudintermedius is probably 171 the most significant species of the SIG, being an important canine opportunistc pathogen, 172 often isolated from dermatitis, otitis and other secondary infections in dogs (Bannoehr et al., 
2007). Since $S$. pseudintermedius produces toxins analogous to the $a g r$ dependend toxins of $S$. aureus, it has been hypothesized that the $S$. pseudintermedius toxins are regulated by a comparable QS mechanism (Sung et al., 2006). However, the Staphylococcus spp. of the SIG differ from all other Staphylococcus spp., including S. aureus, in the fact that their AIP contains a lactone in stead of a thiolactone ring (Dufour et al., 2002; Ji et al., 2005; Novick and Geisinger, 2008). This nonapeptide shows both auto-inducing and cross-inhibiting activities (Ji et al., 2005). DNA sequencing revealed the presence of four predicted AIP variants within the SIG (Bannoehr et al., 2007). Novick and Geisinger (2008) suggest that the divergence of the lactone containing AIP of the SIG from the thiolactone containing AIP of $S$. aureus, may be correlated to the divergence of $S$. pseudintermedius towards the canine host. However, the fact that no association could be made between the AIP variants of the SIG and the different host species, disease status of the host, clinical or geographic origin of the strains might nuance this hypothesis (Bannoehr et al., 2007).

\section{Pseudomonas aeruginosa}

Pseudomonas aeruginosa ( $P$. aeruginosa) is an important opportunistic pathogen in human and veterinary medicine. Pseudomonas infections are difficult to treat since this bacterium is resistant to several antimicrobial agents (Rubin et al., 2008; Weese, 2008) and its antimicrobial susceptibility is even lower when it is present in biofilms (Haesebrouck et al., 2007; Girard and Bloemberg, 2008). P. aeruginosa may cause various tissue infections in different animal species, which illustrates the adaptability of this bacterium. A multitude of virulence factors are regulated by at least one of the 2 different QS systems present in $P$. aeruginosa: Las and Rhl (Whiteley et al., 1999; Girard and Bloemberg, 2008).

Pseudomonas is notorious for its capability to form biofilms. Through the formation of a biofilm, the bacteria are able to colonize all kinds of animal tissues, plants and inert 
surfaces, thereby increasing environmental persistence (Haesebrouck et al., 2007). In addition,

199 bacteria inside a biofilm are difficult to kill either by antimicrobial substances or by host 200 defense mechanisms, and therefore often result in chronic infections that do not respond to 201 antimicrobial therapy. Since $P$. aeruginosa is found ubiquitously in water, wet surfaces are 202 predisposed to be colonized with a $P$. aeruginosa biofilm. In veterinary medicine, the biofilm 203 producing capability of $P$. aeruginosa is most feared in cases of infections involving invasive 204 devices or implants (Weese et al., 2008). P. aeruginosa is also a severe complicating factor in cases of equine ulcerative keratitis (Keller and Hendrix, 2005), in dermatitis, otitis externa and urinary tract infections in small animals (Rubin et al., 2008), in fleece rot in sheep (Kingsford and Raadsma, 1997), in bovine mastitis, which is often associated with contaminated udder washing water or contaminated intramammary dry-cow preparations (McLennan et al., 1997), and in hemorrhagic pneumonia in mink (Hammer et al., 2003). showed that $P$. aeruginosa canine otitis externa isolates share a deficiency of one or more components of the Rhl QS system, leading to the loss of the elastase virulence factor. The

213 virulence factor that favors colonization of canine ears may be under the negative control of 214 the QS system, or a factor that facilitates removal of the bacterium from the canine ears may 215 be under the positive control of Rhl. The authors postulate that either this phenotype might be present before infection or else it might be acquired after infection in an effort to adapt to the

217 novel environment. Recent research suggests an alternative explanation for the presence of 218 QS deficient strains on sites where it can be expected that biofilm formation should be 219 favourable for colonization. Evolutionary biologists describe the phenomenon of 'cheating' 220 individuals in the population (Dunny et al., 2008). Such cheaters profit from the benefits of 221 the cooperating population, without contributing to the community. Since these cheaters do not invest in the production of the biofilm, they have a competitive advantage relative to the 
223 biofilm producing individuals and, as a consequence, can become predominant in the 224 community. However, when the proportion of cheaters becomes too large, this can affect the stability of the biofilm and the entire population may crash as a result (Dunny et al., 2008).

\section{Salmonella}

Several QS systems have been described in Salmonella. Salmonella has a LuxR homologue, SdiA, but does not have a luxI homologue and therefore does not produce AHLs (Walters and Sperandio, 2006). It has been suggested that SdiA senses AHLs produced by other bacterial species (Michael et al., 2001) and in this way senses the presence of the intestinal environment. SdiA regulates the expression of virulence genes with different 233 functions, ranging from resistance to complement killing to the expression of fimbriae. In 234 murine, poultry or bovine models, however, an sdiA mutant strain is not attenuated and, very recently, SdiA dependent gene expression was shown to be activated in the gut of turtles, but not in the intestines of several homoiothermic animal species (Smith et al., 2008). The role of SdiA in Salmonella pathogenesis therefore still remains largely unknown.

In Salmonella enterica subspecies enterica serotype Typhimurium (Salmonella

239 Typhimurium), the $\operatorname{luxS}$ gene is directly involved in the AI-2 synthesis. It was recently 240 demonstrated that luxS and the Salmonella AI-2, 4,5dihydroxy-2,3-pentanedione (DPD), are 241 necessary for Salmonella virulence (Choi et al., 2007). Deletion mutants lacking the luxS gene 242 are severely attenuated in the expression of the virulence genes of the Salmonella 243 Pathogenicity Island 1 (SPI-1). These genes are required for the efficient invasion of intestinal 244 epithelial cells and are therefore crucial in the pathogenesis of Salmonella infections in a wide 245 variety of animal hosts, including poultry, pigs and cattle (Morgan et al., 2004; Bohez et al., 246 2006; Boyen et al., 2006). This finding suggests that Salmonella might secure the initial 
infection process by producing SPI-1 virulence factors only when its population size attains a 248 high enough level (Choi et al., 2007).

Eukaryotic cells communicate with each other using various hormones or hormone-

250 like substances, for example epinephrine and norepinephrine. These signals can be misused, 251 however, by bacterial pathogens, such as Salmonella, to colonize the host or to induce disease 252 (Walters and Sperandio, 2006). Catecholamines may stimulate Salmonella Typhimurium by 253 two mechanisms: as a quorum sensing signal or as a supplier of iron (Bearson et al., 2008). In 254 Salmonella, the QseC AI-3 sensor, which is able to detect norepinephrine, has also been 255 implicated in the regulation of virulence traits such as motility and in vivo competitive fitness in pigs (Bearson and Bearson, 2008). Even though the role of catecholamines or even other neurotransmittors or hormones in the pathogenesis of Salmonella infections is still in its infancy, the ability to respond to norepinephrine produced by the host has potential food safety consequences. The mechanism described above may be one of the factors causing the sudden burst of Salmonella excretion by stressed pigs, for example, during transport to the slaughter house (Bearson and Bearson, 2008).

\section{Other veterinary pathogens}

It has been shown that several Pasteurellaceae, including Mannheimia haemolytica,

Actinobacillus pleuropneumoniae, contain LuxS homologues in their genome and are able to

268 produce AI-2-like molecules (Malott and Lo, 2002). Also in Histophilus somni, QS may 269 contribute to pathogenesis (Corbeil, 2007). A luxS deletion mutant in Mannheimia 270 haemolytica did not show altered leukotoxin expression levels, but had increased expression 271 levels of putative virulence genes such as a transferrin binding protein, an adhesin and capsule 
272 biosynthesis, and was outcompeted by the wild type parent strain in a calf challenge model 273 (van der Vinne et al., 2005). Very recently, a luxS deletion mutant of Actinobacillus 274 pleuropneumoniae was shown to be significantly attenuated in an in vivo mouse model (Li et 275 al., 2008). The down-regulation of the apxIIA toxin, a major virulence factor of 276 Actinobacillus pleuropneumoniae, may contribute to the virulence attenuation of the luxS 277 deletion mutant (Li et al., 2008).

278 There are numerous studies dealing with the role of QS in the pathogenesis of 279 infections with EHEC (e.g. Kendall and Sperandio, 2007), but studies of the importance of 280 QS in infections with E. coli in veterinary medicine are scarce. Recently, a luxS deletion 281 mutant of a rabbit enteropathogenic E. coli (EPEC) strain was found to be impaired in its 282 virulence in vitro, but was not attenuated in experimentally infected rabbits (Zhu et al., 2007). 283 Even though QS was initially described and thoroughly examined in several Vibrio 284 spp., reports linking the QS mechanisms to virulence in fish are much more limited, both for 285 Vibrio spp. (Bruhn et al., 2005; Austin and Zhang, 2006; Nelson et al., 2007;Ye et al., 2008) 286 and non-Vibrio fish pathogens (Morohoshi et al., 2004; Bruhn et al., 2005; Atkinson et al., 287 2006; Bi et al., 2007; Rasch et al., 2007).

288 Quorum sensing has been described in various other veterinary or zoonotic pathogens, 289 such as Clostridium perfringens (Ohtani et al., 2002), Yersinia pseudotuberculosis (Atkinson 290 et al., 2008) and Campylobacter jejuni (Jeon et al., 2005; He et al., 2008), but a clear 291 correlation between these QS mechanisms and virulence is yet to be demonstrated. 
FUTURE PERSPECTIVES OF QUORUM SENSING IN VETERINARY MEDICINE

Quorum sensing signal molecule detection as a diagnostic tool?

Since bacterial quorum sensing has been implicated in the onset of bacterial pathogenicity (Wu et al., 2000; Kendall and Sperandio, 2007), the signal molecules produced

300 by the bacterial pathogens are potential biomarkers for the diagnosis and follow-up of bacterial infections (Kumari et al., 2008). Because the chemical structure of the various signal molecules differ greatly, different sensory systems for detecting these molecules have been described (Kalkum et al., 2003; Steindler and Venturi, 2007; Kumari et al., 2008). Most of the studies dealing with the detection of QS signal molecules, however, focus on the detection of AHLs, since these molecules are involved in the development of chronic bacterial infections with $P$. aeruginosa or Burkholderia cepacia in the lungs of cystic fibrosis patients in human medicine (Kumari et al., 2008). Despite the plethora of detection systems, only a fraction can be used to detect QS signal molecules in clinical samples (Kumari et al., 2008).

AHLs of various Gram-negative bacterial pathogens have been detected in clinical samples of sputum, mucopurulent secretions of the respiratory tract, lung, liver and spleen 311 homogenates and feces of humans and/or experimentally infected mice (Middleton et al., 312 2002; Jacobi et al., 2003; Kumari et al., 2006; Kumari et al., 2008). In bronchoalveolar 313 lavages (BALs) from transplanted human lungs, long-chain AHLs were detected, even in 314 lungs that were clinically stable and showed no signs of bacterial infection (Ward et al., 315 2003). Therefore, the detection of QS signal molecules as a means to detect bacterial 316 infections in a very early stage merits further attention. There are currently no reports of 317 detections of QS signal molecules of veterinary bacterial pathogens in clinical samples of 318 animal host species of veterinary importance. 
Quorum sensing inhibition as a therapeutic tool?

The concept of QS inhibition, as used by a range of prokaryotic and eukaryotic organisms, is not new. For example, certain $S$. aureus strains produce auto-inducers that stimulate their own QS mechanisms, but have a cross-inhibitory effect on the QS systems of other strains, possibly excluding them from infection or colonization sites (Ji et al., 1997). Certain Bacillus sp. harbour the acyl-homoserine lactonase enzyme, which inactivates AHL activity by hydrolysing the lactone bond of AHLs of competing bacterial species (Dong et al., 2001). The fact that certain human cell lines are able to inactivate QS signal molecules suggests that mammalian host defences might have developed interfering QS systems against bacterial infections as well (Chun et al., 2004). development of novel therapeutic agents. It is clear that QS is a key regulatory system in the pathogenesis of various bacterial infections. Therefore, the targeting of the QS mechanisms provides a novel strategy for combating bacterial infections (Bjarnsholt and Givskov, 2007).

334 These compounds ideally have no direct effect on bacterial growth, but attenuate bacterial 335 pathogenicity, thereby increasing the susceptibility of the pathogen to the host defences. Even though the macrolides may show potential as QS inhibitors (Tateda et al., 2007), the lack of an effect of "pure" QS inhibitors on bacterial growth could mean a strong advantage relative to the "classic" antimicrobial agents, since the use of these products may not exert a strong 339 selective pressure towards the development of resistance.

$340 \quad$ Very recently, a small molecule, LED209, was discovered using a high-throughput 341 screening which inhibits the QseC mediated activation of virulence gene expression and 342 subsequent in vivo virulence of various bacterial pathogens, such as EHEC, Salmonella 343 Typhimurium and Francisella tularensis (Rasko et al., 2008). Being non-toxic for mammals, 
344 having a broad spectrum and lacking a direct effect on bacterial growth, this molecule holds a 345 promising future (Rasko et al., 2008).

346 Inhibition of biofilm formation has been described using QS inhibitors in $P$. 347 aeruginosa (Bjarnsholt and Givskov, 2007), S. aureus (Wright et al., 2005) and Salmonella 348 Typhimurium (Janssens et al., 2007).

349 Research aimed at the use of QS inhibitors in veterinary medicine is currently limited 350 to their use in aquaculture. For the fish pathogens Aeromonas salmonicida and Vibrio 351 (Listonella) anguillarum, AHL analogues reduced the virulence gene expression and the fish 352 mortality rates, respectively (Rasch et al., 2004; Rasch et al., 2007).

\section{CONCLUSION}

355 Quorum sensing is a widespread phenomenon used by various bacterial pathogens of 356 veterinary importance. Different QS mechanisms make use of diverse signal molecules, 357 leading to intraspecies, interspecies and even interkingdom signalling. Since QS probably 358 plays a role in the pathogenesis of many bacterial infections in animals, the detection of QS 359 signal molecules at early stages of the infection and the use of QS inhibitors for treatment 360 may provide new tools in future veterinary medicine. 
REFERENCES

Atkinson, S., Sockett, R.E., Cámara, M., Williams, P., 2006. Quorum sensing and the lifestyle of Yersinia. Curr. Issues Mol. Biol. 8, 1-10.

Atkinson, S., Chang, C.Y., Patrick, H.L., Buckley, C.M., Wang, Y., Sockett, R.E., Cámara, M., Williams, P., 2008. Functional interplay between the Yersinia pseudotuberculosis

Austin, B., Zhang, X.H. (2006). Vibrio harveyi: a significant pathogen of marine vertebrates and invertebrates. Lett. Appl. Microbiol. 43, 119-124.

Bearson, B.L., Bearson, S.M., 2007. The role of the QseC quorum-sensing sensor kinase in colonization and norepinephrine-enhanced motility of Salmonella enterica serovar Typhimurium. Microb. Pathog. 44, 271-278.

Bearson, B.L., Bearson, S.M., Uthe, J.J., Dowd, S.E., Houghton, J.O., Lee, I., Toscano, M.J., Lay, D.C. Jr., 2008. Iron regulated genes of Salmonella enterica serovar Typhimurium in response to norepinephrine and the requirement of fepDGC for norepinephrineenhanced growth. Microbes Infect. 10, 807-816.

Bi, Z.X., Liu, Y.J., Lu, C.P., 2007. Contribution of AhyR to virulence of Aeromonas hydrophila J-1. Res. Vet. Sci. 83, 150-156.

Bjarnsholt, T., Givskov, M., 2007. Quorum-sensing blockade as a strategy for enhancing host defences against bacterial pathogens. Philos. Trans. R. Soc. Lond. B Biol. Sci. 362, 1213-1222.

Bohez, L., Ducatelle, R., Pasmans, F., Botteldoorn, N., Haesebrouck, F., Van Immerseel, F., 2006. Salmonella enterica serovar Enteritidis colonization of the chicken caecum requires the HilA regulatory protein. Vet. Microbiol.116, 202-210.

Boles, B.R., Horswill, A.R., 2008. Agr-mediated dispersal of Staphylococcus aureus biofilms. PLoS Pathog. 4, e1000052.

Booth, M.C., Atkuri, R.V., Nanda, S.K., Iandolo, J.J., Gilmore, M.S., 1995. Accessory gene regulator controls Staphylococcus aureus virulence in endophthalmitis. Invest. Ophthalmol. Vis. Sci.. 36, 1828-1836.

Boyen, F., Pasmans, F., Van Immerseel, F., Morgan, E., Adriaensen, C., Hernalsteens, J.-P., Decostere, A., Ducatelle, R., Haesebrouck, F. (2006). Salmonella Typhimurium SPI-1 
genes promote intestinal but not tonsillar colonization in pigs. Microbes Infect. 8, 2899-2907.

Bruhn, J.B., Dalsgaard, I., Nielsen, K.F., Buchholtz, C., Larsen, J.L., Gram, L., 2005. Quorum sensing signal molecules (acylated homoserine lactones) in gram-negative fish pathogenic bacteria. Dis. Aquat. Organ. 65, 43-52.

401

402

403

404

405

406

407

408

409

410

411

412

413

414

415

416

417

418

419

420

421

422

423

424

425

426

427

428

Buzzola, F.R., Alvarez, L.P., Tuchscherr, L.P., Barbagelata, M.S., Lattar, S.M., Calvinho, L., Sordelli, D.O., 2007. Differential abilities of capsulated and noncapsulated Staphylococcus aureus isolates from diverse agr groups to invade mammary epithelial cells. Infect. Immun. 75, 886-891.

Cheung, A.L., Eberhardt, K.J., Chung, E., Yeaman, M.R., Sullam, P.M., Ramos, M., Bayer, A.S., 1994. Diminished virulence of a sar-/agr- mutant of Staphylococcus aureus in the rabbit model of endocarditis. J. Clin. Invest. 94, 1815-1822.

Choi, J., Shin, D., Ryu, S., 2007. Implication of quorum sensing in Salmonella enterica serovar typhimurium virulence: the $\operatorname{lux} S$ gene is necessary for expression of genes in pathogenicity island 1. Infect. Immun. 75, 4885-4890.

Chun, C.K., Ozer, E.A., Welsh, M.J., Zabner, J., Greenberg, E.P., 2004. Inactivation of a Pseudomonas aeruginosa quorum-sensing signal by human airway epithelia. Proc. Natl. Acad. Sci. U. S. A. 101, 3587-3590.

Corbeil, L.B., 2007. Histophilus somni host-parasite relationships. Anim. Health Res. Rev. 8, 151-160.

Devriese, L.A., Hermans, K., Baele, M., Haesebrouck, F., 2009. Staphylococcus pseudintermedius versus Staphylococcus intermedius.Vet. Microbiol. 133, 206-207.

Devriese, L.A., Vancanneyt, M., Baele, M., Vaneechoutte, M., De Graef, E., Snauwaert, C., Cleenwerck, I., Dawyndt, P., Swings, J., Decostere, A., Haesebrouck, F., 2005. Staphylococcus pseudintermedius sp. nov., a coagulase-positive species from animals. Int. J. Syst. Evol. Microbiol. 55, 1569-1573.

Dirix, G., Monsieurs, P., Dombrecht, B., Daniels, R., Marchal, K., Vanderleyden, J., Michiels, J., 2004. Peptide signal molecules and bacteriocins in Gram-negative bacteria: a genome-wide in silico screening for peptides containing a double-glycine leader sequence and their cognate transporters. Peptides. 25, 1425-1440.

Dong, Y.H., Wang, L.H., Xu, J.L., Zhang, H.B., Zhang, X.F., Zhang, L.H., 2001. Quenching quorum-sensing-dependent bacterial infection by an $\mathrm{N}$-acyl homoserine lactonase. Nature 411, 813-817. 
Dufour, P., Jarraud, S., Vandenesch, F., Greenland, T., Novick, R.P., Bes, M., Etienne, J., Lina, G., 2002. High genetic variability of the agr locus in Staphylococcus species. J. Bacteriol. 184, 1180-1186.

Dunny, G.M., Brickman, T.J., Dworkin, M., 2008. Multicellular behavior in bacteria: communication, cooperation, competition and cheating. Bioessays 30, 296-298.

Fuqua, C., Parsek, M.R., Greenberg, E.P., 2001. Regulation of gene expression by cell-to-cell communication: acyl-homoserine lactone quorum sensing. Annu. Rev. Genet. 35, 439468 .

Gillaspy, A.F., Hickmon, S.G., Skinner, R.A., Thomas, J.R., Nelson, C.L., Smeltzer, M.S., 1995. Role of the accessory gene regulator (agr) in pathogenesis of staphylococcal osteomyelitis. Infect. Immun. 63, 3373-3380.

Girard, G., Bloemberg, G.V., 2008. Central role of quorum sensing in regulating the production of pathogenicity factors in Pseudomonas aeruginosa. Future Microbiol. 3, 97-106.

Goerke, C., Kummel, M., Dietz, K., Wolz, C., 2003. Evaluation of intraspecies interference due to agr polymorphism in Staphylococcus aureus during infection and colonization. J. Infect. Dis. 188, 250-256.

Haesebrouck, F., Van Immerseel, F., Hermans, K., Martel, A., Ducatelle, R. Pasmans, F., 2007. Biofilms: Betekenis voor de behandeling en bestrijding van bacteriële infecties bij huisdieren. Vlaams Diergen. Tijds. 76, 331-336.

Hajek, V., 1976. Staphylococcus intermedius, a new species isolated from animals, Int. J. Syst. Bacteriol. 26, 401-408.

Hammer, A.S., Pedersen, K., Andersen, T.H., Jørgensen, J.C., Dietz, H.H., 2003. Comparison of Pseudomonas aeruginosa isolates from mink by serotyping and pulsed-field gel electrophoresis. Vet. Microbiol. 94, 237-243.

Hardie, K.R., Heurlier, K., 2008. Establishing bacterial communities by 'word of mouth': LuxS and autoinducer 2 in biofilm development. Nat. Rev. Microbiol. 6, 635-643.

He, Y., Frye, J.G., Strobaugh, T.P., Chen, C.Y., 2008. Analysis of AI-2/LuxS-dependent transcription in Campylobacter jejuni strain 81-176. Foodborne Pathog. Dis. 5, 399415.

Irie, Y., Parsek, M.R., 2008. Quorum sensing and microbial biofilms. Curr. Top. Microbiol. Immunol. 322, 67-84. 
461

462

463

464

465

466

467

468

469

470

471

472

473

474

475

476

477

478

479

480

481

482

483

484

485

486

487

488

489

490

491

492

493

Jacobi, C.A., Bach, A., Eberl, L., Steidle, A., Heesemann, J., 2003. Detection of N-(3oxohexanoyl)-L-homoserine lactone in mice infected with Yersinia enterocolitica serotype O8. Infect. Immun. 71, 6624-6626.

Janssens, J.C., Steenackers, H., Metzger, K., Daniels, R., Ptacek, D., Verhoeven, T., Hermans, K., Vanderleyden, J., De Vos, D.E., De Keersmaecker, S.C., 2007. Interference with the quorum sensing systems of Salmonella enterica serovar typhimurium: possibilities and implications. Commun. Agric. Appl. Biol. Sci. 72, 35-39.

Jeon, B., Itoh, K., Ryu, S., 2005. Promoter analysis of cytolethal distending toxin genes (cdtA , B, and C ) and effect of a luxS mutation on CDT production in Campylobacter jejuni. Microbiol. Immunol. 49, 599-603.

Ji, G., Beavis, R., Novick, R.P., 1997. Bacterial interference caused by autoinducing peptide variants. Science 276, 2027-2030.

Kalkum, M., Lyon, G.J., Chait, B.T., 2003. Detection of secreted peptides by using hypothesis-driven multistage mass spectrometry. Proc. Natl. Acad. Sci. U. S. A. 100, 2795-2800.

Karch, H., Tarr, P.I., Bielaszewska, M., 2005. Enterohaemorrhagic Escherichia coli in human medicine. Int. J. Med. Microbiol. 295, 405-418.

Keller, R.L., Hendrix, D.V., 2005. Bacterial isolates and antimicrobial susceptibilities in equine bacterial ulcerative keratitis (1993--2004). Equine Vet. J. 37, 207-211.

Kendall, M.M., Sperandio, V., 2007. Quorum sensing by enteric pathogens. Curr. Opin. Gastroenterol. 23, 10-15.

Kingsford, N.M., Raadsma, H.W., 1997. The occurrence of Pseudomonas aeruginosa in fleece washings from sheep affected and unaffected with fleece rot. Vet. Microbiol. 54, 275-285.

Kleerebezem, M., 2004. Quorum sensing control of lantibiotic production; nisin and subtilin autoregulate their own biosynthesis. Peptides 25, 1405-1414.

Kumari, A., Pasini, P., Daunert, S., 2008. Detection of bacterial quorum sensing N-acyl homoserine lactones in clinical samples. Anal. Bioanal. Chem. 391, 1619-1627.

Kumari, A., Pasini, P., Deo, S.K., Flomenhoft, D., Shashidhar, H., Daunert, S., 2006. Biosensing systems for the detection of bacterial quorum signaling molecules. Anal. Chem. 78, 7603-7609.

Lazazzera, B.A., 2000. Quorum sensing and starvation: signals for entry into stationary phase. Curr. Opin. Microbiol. 3, 177-182. 
Li, L., Zhou, R., Li, T., Kang, M., Wan, Y., Xu, Z., Chen, H., 2008. Enhanced biofilm formation and reduced virulence of Actinobacillus pleuropneumoniae luxS mutant. Microb. Pathog. 45, 192-200.

Lyon, G.J., Novick, R.P., 2004. Peptide signaling in Staphylococcus aureus and other Grampositive bacteria. Peptides. 25, 1389-1403.

Malott, R.J., Lo, R.Y., 2002. Studies on the production of quorum-sensing signal molecules in Mannheimia haemolytica A1 and other Pasteurellaceae species. FEMS Microbiol. Lett. 206, 25-30.

McLennan, M.W., Kelly, W.R., O'Boyle, D., 1997. Pseudomonas mastitis in a dairy herd. Aust. Vet. J. 75, 790-792.

Melchior, M.B., van Osch, M.H.J., Graat, R.M., van Duijkeren, E., Mevius, D.J., Nielen, M., Gaastra, W., Fink-Gremmels, J. (2009). Biofilm formation and genotyping of Staphylococcus aureus bovine mastitis isolates: evidence for lack of penicillinresistance in $A g r$ - type II strains., Vet. Microbiol., in press.

doi:10.1016/j.vetmic.2008.12.004

Michael, B., Smith, J.N., Swift, S., Heffron, F., Ahmer, B.M., 2001. SdiA of Salmonella enterica is a LuxR homolog that detects mixed microbial communities. J. Bacteriol. $183,5733-5742$.

Middleton, B., Rodgers, H.C., Cámara, M., Knox, A.J., Williams, P., Hardman, A., 2002. Direct detection of $\mathrm{N}$-acylhomoserine lactones in cystic fibrosis sputum. FEMS Microbiol. Lett. 207, 1-7.

Morgan, E., Campbell, J.D., Rowe, S.C., Bispham, J., Stevens, M.P., Bowen, A.J., Barrow, P.A., Maskell, D.J., Wallis, T.S. (2004). Identification of host-specific colonization factors of Salmonella enterica serovar Typhimurium. Mol. Microbiol. 54, 994-1010.

Moré, M.I., Finger, L.D., Stryker, J.L., Fuqua, C., Eberhard, A., Winans, S.C., 1996. Enzymatic synthesis of a quorum-sensing autoinducer through use of defined substrates. Science. 272, 1655-1658.

Morohoshi, T., Inaba, T., Kato, N., Kanai, K., Ikeda, T., 2004. Identification of quorumsensing signal molecules and the LuxRI homologs in fish pathogen Edwardsiella tarda. J. Biosci. Bioeng. 98, 274-281.

Moxley, R.A., 2004. Escherichia coli 0157:H7: an update on intestinal colonization and virulence mechanisms. Anim. Health. Res. Rev. 5, 15-33.

Nealson, K.H., Platt, T., Hastings, J.W., 1970. Cellular control of the synthesis and activity of the bacterial luminescent system. J. Bacteriol. 104, 313-322. 
Neiditch, M.B., Federle, M.J., Miller, S.T., Bassler, B.L., Hughson, F.M., 2005. Regulation of LuxPQ receptor activity by the quorum-sensing signal autoinducer-2. Mol. Cell. 18, 507-518.

Nelson, E.J., Tunsjø, H.S., Fidopiastis, P.M., Sørum, H., Ruby, E.G., 2007. A novel lux operon in the cryptically bioluminescent fish pathogen Vibrio salmonicida is associated with virulence. Appl. Environ. Microbiol. 73, 1825-1833.

Novick, R.P., 2003. Autoinduction and signal transduction in the regulation of staphylococcal virulence. Mol. Microbiol. 48, 1429-1449.

Novick, R.P., Geisinger, E., 2008. Quorum sensing in staphylococci. Annu. Rev. Genet. 42, 541-564.

Ohtani, K., Hayashi, H., Shimizu, T., 2002. The luxS gene is involved in cell-cell signalling for toxin production in Clostridium perfringens. Mol. Microbiol. 44, 171-179.

Rajamani, S., Zhu, J., Pei, D., Sayre, R., 2007. A LuxP-FRET-based reporter for the detection and quantification of AI-2 bacterial quorum-sensing signal compounds. Biochemistry. 46, 3990-3997.

Rasch, M., Buch, C., Austin, B., Slierendrecht, W.J., Ekmann, K.S., Larsen, J.L., Johansen, C., Riedel, K., Eberl, L., Givskov, M., Gram, L., 2004. An inhibitor of bacterial quorum sensing reduces mortalities caused by Vibriosis in rainbow trout (Oncorhynchus mykiss, Walbaum). Syst. Appl. Microbiol. 27, 350-359.

Rasch, M., Kastbjerg, V.G., Bruhn, J.B., Dalsgaard, I., Givskov, M., Gram, L., 2007. Quorum sensing signals are produced by Aeromonas salmonicida and quorum sensing inhibitors can reduce production of a potential virulence factor. Dis. Aquat. Organ. 78, 105-113.

Rasko, D.A., Moreira, C.G., Li, de R., Reading, N.C., Ritchie, J.M., Waldor, M.K., Williams, N., Taussig, R., Wei, S., Roth, M., Hughes, D.T., Huntley, J.F., Fina, M.W., Falck, J.R., Sperandio, V., 2008. Targeting QseC signaling and virulence for antibiotic development. Science 321, 1078-1080.

Rezzonico, F., Duffy, B., 2008. Lack of genomic evidence of AI-2 receptors suggests a nonquorum sensing role for luxS in most bacteria. BMC Microbiol. 8, 154.

Rubin, J., Walker, R.D., Blickenstaff, K., Bodeis-Jones, S., Zhao, S., 2008. Antimicrobial resistance and genetic characterization of fluoroquinolone resistance of Pseudomonas aeruginosa isolated from canine infections. Vet. Microbiol. 131, 164-172.

Salmond, G.P.C., Bycroft, B.W., Stewart, G.S.A.B., Williams, P., 1995. The bacterial 'enigma': cracking the code of cell-cell communication. Mol. Microbiol. 16, 615-624. 
Schauder, S., Shokat, K., Surette, M.G., Bassler, B.L., 2001. The LuxS family of bacterial autoinducers: biosynthesis of a novel quorum-sensing signal molecule. Mol. Microbiol. $41,463-476$.

Smith, D., Wang, J.H., Swatton, J.E., Davenport, P., Price, B., Mikkelsen, H., Stickland, H., Nishikawa, K., Gardiol, N., Spring, D.R., Welch, M., 2006. Variations on a theme: diverse $\mathrm{N}$-acyl homoserine lactone-mediated quorum sensing mechanisms in gramnegative bacteria. Sci. Prog. 89, 167-211.

Smith, J.N., Dyszel, J.L., Soares, J.A., Ellermeier, C.D., Altier, C., Lawhon, S.D., Adams, L.G., Konjufca, V., Curtiss, R. 3rd, Slauch, J.M., Ahmer, B.M., 2008. SdiA, an Nacylhomoserine lactone receptor, becomes active during the transit of Salmonella enterica through the gastrointestinal tract of turtles. PLoS ONE 3, e2826.

Surette, M.G., Miller, M.B., Bassler, B.L., 1999. Quorum sensing in Escherichia coli, Salmonella typhimurium, and Vibrio harveyi: a new family of genes responsible for autoinducer production. Proc. Natl. Acad. Sci. U. S. A. 96, 1639-1644.

Tateda, K., Ishii, Y., Kimura, S., Horikawa, M., Miyairi, S., Yamaguchi, K., 2007. Suppression of Pseudomonas aeruginosa quorum-sensing systems by macrolides: a promising strategy or an oriental mystery? J. Infect. Chemother. 13, 357-367.

Traber, K.E., Lee, E., Benson, S., Corrigan, R., Cantera, M., Shopsin, B., Novick, R.P., 2008. Agr function in clinical Staphylococcus aureus isolates. Microbiology-(UK) 154, 2265-2274.

Tron, E.A., Wilke, H.L., Petermann, S.R., Rust, L., 2004. Pseudomonas aeruginosa from canine otitis externa exhibit a quorum sensing deficiency. Vet. Microbiol. 99, 121-129.

Vancraeynest, D., Haesebrouck, F., Deplano, A., Denis, O., Godard, C., Wildemauwe, C., Hermans, K., 2006. International dissemination of a high virulence rabbit Staphylococcus aureus clone. J. Vet. Med. B Infect. Dis. Vet. Public Health. 53, 418422 .

van der Vinne, A.N., Lo, R.Y., Shewen, P.E., 2005. Construction and analysis of a Mannheimia haemolytica A1 luxS mutant. Vet. Microbiol. 110, 53-66.

Vautor, E., Magnone, V., Rios, G., Le Brigand, K., Bergonier, D., Lina, G., Meugnier, H., Barbry, P., Thiéry, R., Pépin, M., 2008. Genetic differences among Staphylococcus aureus isolates from dairy ruminant species: A single-dye DNA microarray approach. Vet. Microbiol. [Epub ahead of print]: doi:10.1016/j.vetmic.2008.06.006. 
Vendeville, A., Winzer, K., Heurlier, K., Tang, C.M., Hardie, K.R., 2005. Making 'sense' of metabolism: autoinducer-2, LuxS and pathogenic bacteria. Nat. Rev. Microbiol. 3, 383-396.

Walters, M., Sperandio, V., 2006. Quorum sensing in Escherichia coli and Salmonella. Int. J. Med. Microbiol. 296, 125-131.

Ward, C., Cámara, M., Forrest, I., Rutherford, R., Pritchard, G., Daykin, M., Hardman, A., de Soyza, A., Fisher, A.J., Williams, P., Corris, P.A., 2003. Preliminary findings of quorum signal molecules in clinically stable lung allograft recipients. Thorax. 58, 444446.

Waters, C.M., Bassler, B.L., 2005. Quorum sensing: cell-to-cell communication in bacteria. Annu. Rev. Cell. Dev. Biol. 21, 319-346.

Weese, J.S., 2008. A review of multidrug resistant surgical site infections. Vet. Comp. Orthop. Traumatol. 21, 1-7.

Whiteley, M., Lee, K.M., Greenberg, E.P., 1999. Identification of genes controlled by quorum sensing in Pseudomonas aeruginosa. Proc. Natl. Acad. Sci. U. S. A. 96, 13904-13909.

Wright, J.S. $3^{\text {rd }}$, Jin, R., Novick, R.P., 2005. Transient interference with staphylococcal quorum sensing blocks abscess formation. Proc. Natl. Acad. Sci. U. S. A. 102, 16911696.

Wu, H., Song, Z., Hentzer, M., Andersen, J.B., Heydorn, A., Mathee, K., Moser, C., Eberl, L., Molin, S., Høiby, N., Givskov, M., 2000. Detection of N-acylhomoserine lactones in lung tissues of mice infected with Pseudomonas aeruginosa. Microbiology-(UK) 146, 2481-2493.

Xavier, KB, Bassler, BL., 2003. LuxS quorum sensing: more than just a numbers game. Curr. Opin. Microbiol. 6, 191-197.

Ye, J., Ma, Y., Liu, Q., Zhao, D.L., Wang, Q.Y., Zhang, Y.X., 2008. Regulation of Vibrio alginolyticus virulence by the LuxS quorum-sensing system. J. Fish Dis. 31, 161-169.

Zhu, C., Feng, S., Sperandio, V., Yang, Z., Thate, T.E., Kaper, J.B., Boedeker, E.C., 2007. The possible influence of LuxS in the in vivo virulence of rabbit enteropathogenic Escherichia coli. Vet. Microbiol. 125, 313-322. 
625 Figure legend

626

627 Figure 1: The principle of quorum sensing is depicted. In situations where the bacterial 628 density is low (left), the signal molecule concentration is also low and does not exceed the 629 quorum sensing treshold. In case the bacterial density is high (right), the signal molecule 630 concentration is also high and the quorum sensing treshold is exceeded. As a result, the signal 631 molecules are bound to their receptors on the bacterial cells and the gene expression of the 632 total population is changed and synchronised.

633

634 Figure 2: Four simplified models of the described quorum sensing mechanisms. 


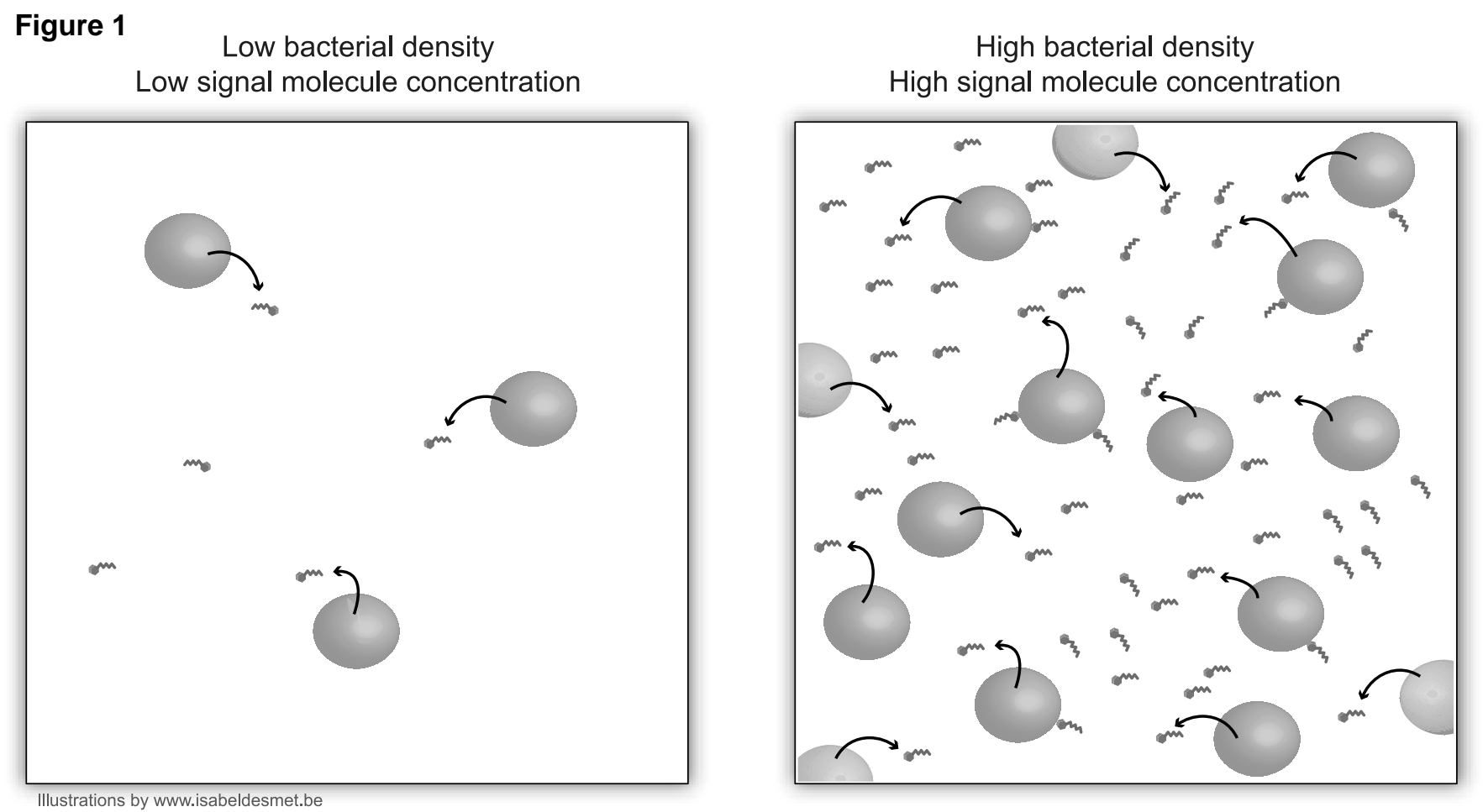




\section{MECHANISM 1}

Quorum sensing in mainly $\mathrm{Gr}+$ bacteria: autoinducing polypeptides (AIP)

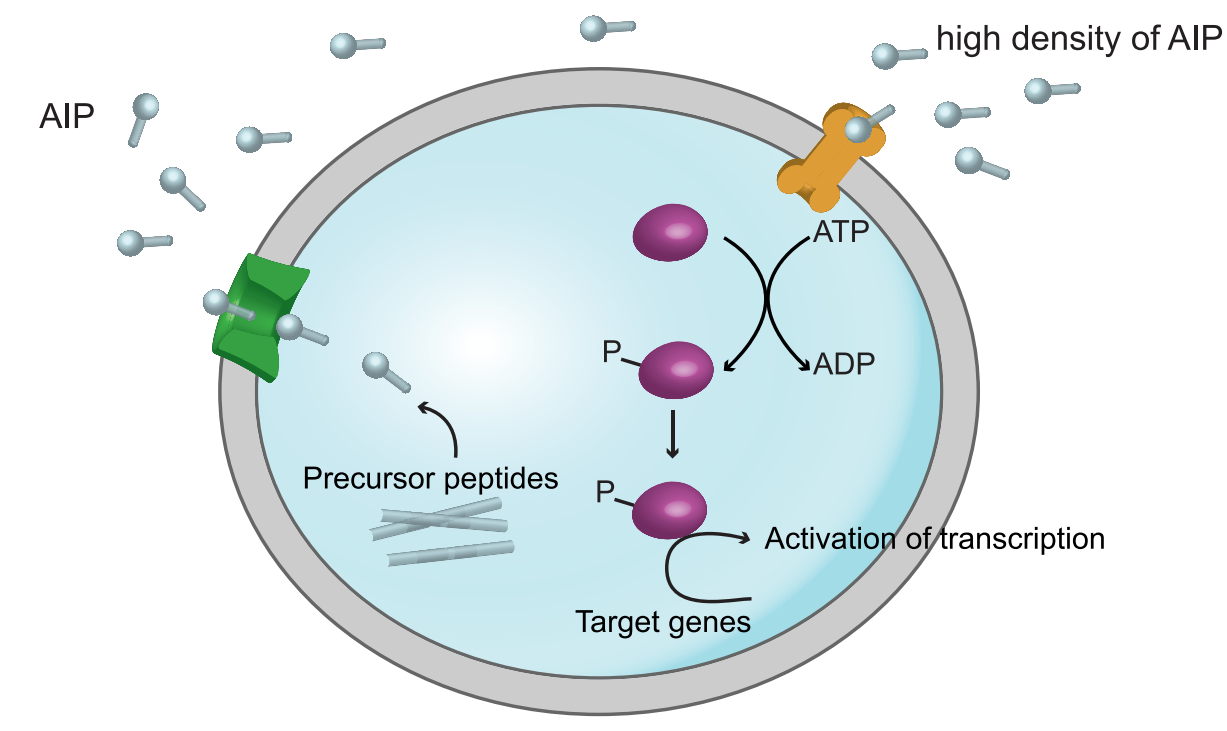

MECHANISM 2

Quorum sensing in $\mathrm{Gr}$ - bacteria: N-acylhomoserine lactones (AHL / Al-1)

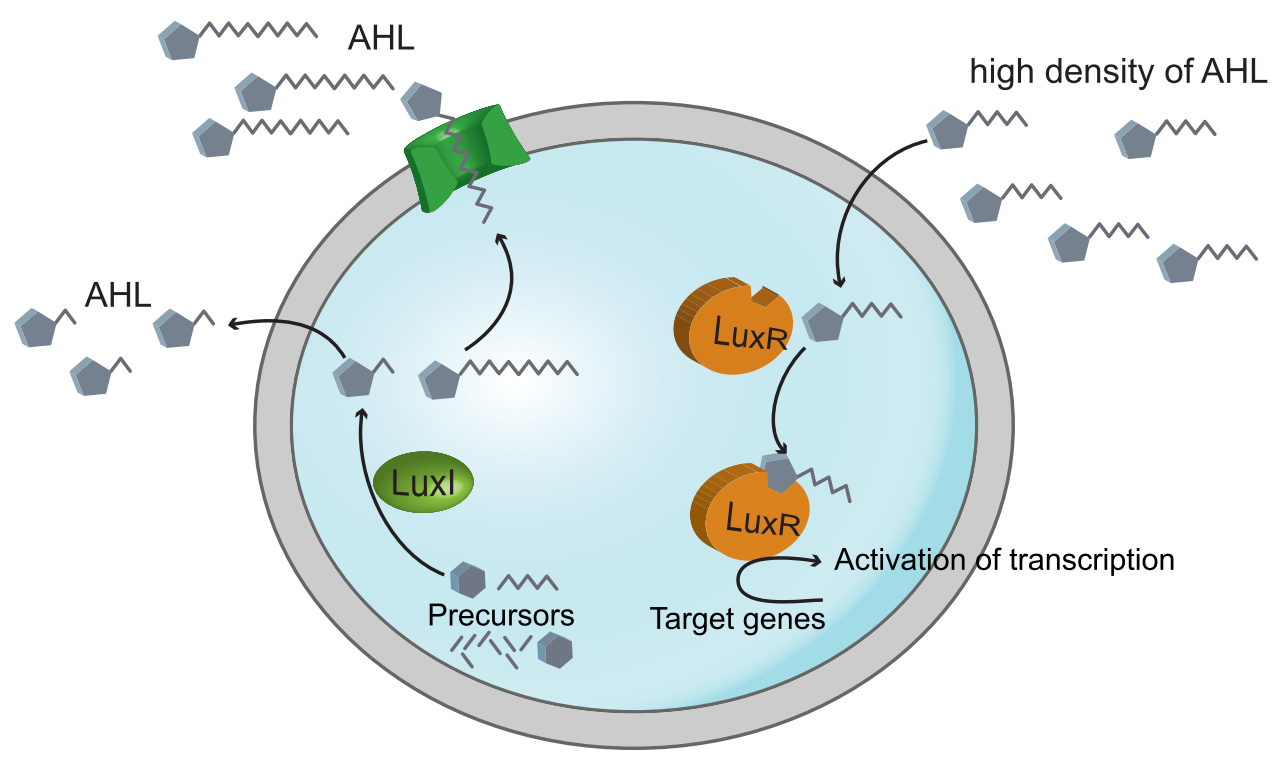

MECHANISM 3

Quorum sensing in both $\mathrm{Gr}+$ and $\mathrm{Gr}$ - bacteria: autoinducer 2 (Al-2)

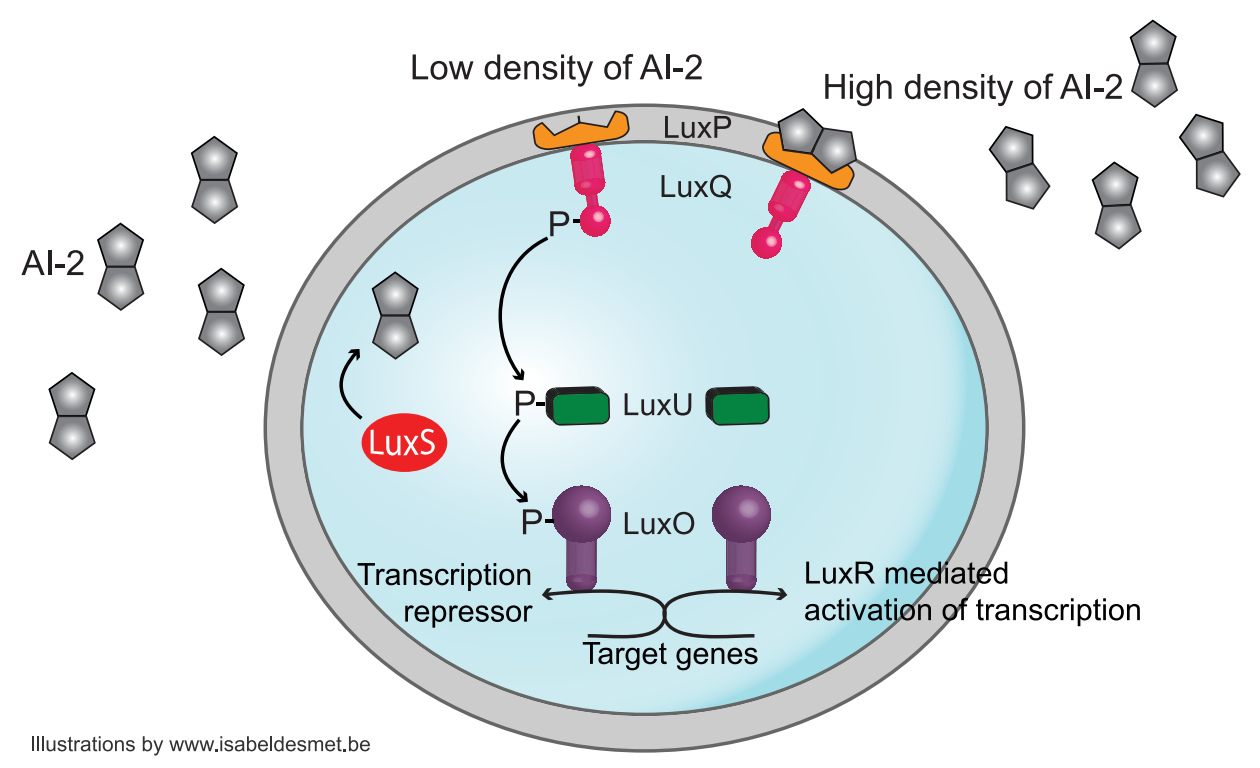

MECHANISM 4

Quorum sensing beyond bacterial borders: autoinducer 3 (Al-3)

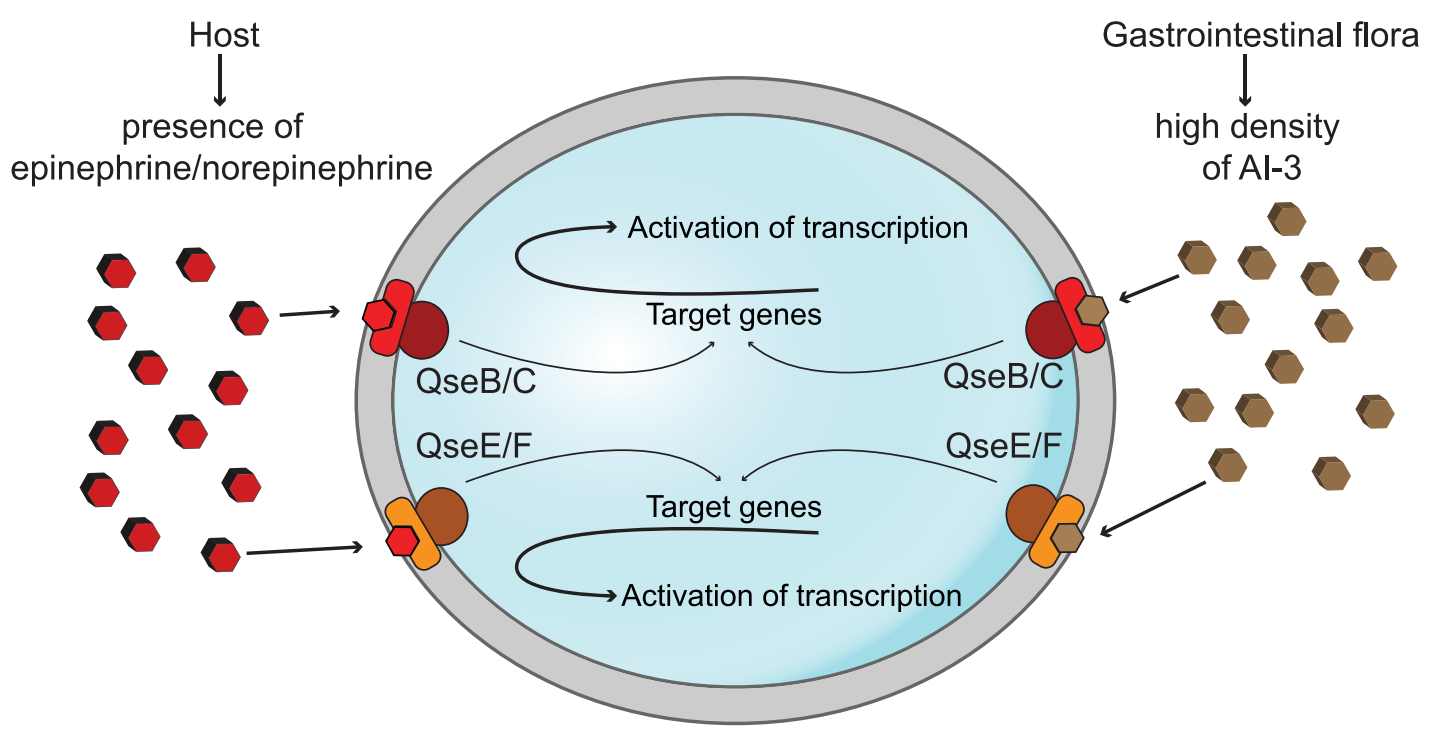

